\title{
Law Reform in Africa: A Comparative Study of the Tanzanian and Kenyan Experiments
}

\author{
By D. R. Salter and J. B. Ojwang
}

\section{A. The Philosophical Framework of Law Reform}

The modern State, everywhere, is a monopolist of the most critical devices and instrumentalities of public authority. A constant element in this monopoly is the centralised, or increasingly centralised legal system, marked by a State-controlled core of supporting sanctions. In the older, more established nations, with more tested traditions of government, there exists, in most cases, no more than one recognised legal system - a system that operates conjointly with a set of authoritative public sanctions superintended by the State. ${ }^{1}$

Ideally, a legal system should serve, inter alia, the following functions: (i) furnishing a framework for stability in the principal institutions in operation amongst a people; (ii) supplying rules and procedures of regularity, to govern and facilitate interactions amongst individuals, groups and societal organs, without permitting undue disturbance in the equilibrium of the principal institutions themselves; (iii) providing a framework of norms conducive to the promotion of basic virtues (such as discipline, efficiency, thrift) and the suppression of common abuses (such as inefficiency, highhandedness, corrpution, disorder, wastage); (iv) availing principles and procedures for fair and harmonious dispute settlement, on the basis of a common acceptance of the fundamental institutions in operation.

However, legal systems of ten reflect the practices and usages of the day, and generally are not part of a deliberate calculation motivated by considerations of efficiency, harmony, order etc. The older a unified legal system is, the higher are the chances that it has incorporated to a greater degree the attributes aforementioned; but the newer it is, the greater is the likelihood that the extent of development is only experimental, and that no real equilibrium in the legal system has been attained.

But the above assertion must itself be qualified, in the light of experience so far gained.

* LL.B. (Birmingham); Solicitor; Lecturer in Law, University College of Wales, Aberystwyth.

** LL.B., LL.M. (Nairobi); Ph.D. (Cantab); Advocate of the High Court of Kenya; Senior Lecturer in Law, University of Nairobi.

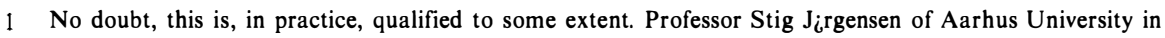
Denmark, for instance, reports "the tendency even in modern Scandinavia where legal sociologists in remote rural societies have found that the medieval customary law has been the living law instead of the official State law" - Stig Jirgensen, "What is Law?", Paper presented at the Canberra Law Workshop VII on Legal Pluralism and Comparative Law, 6-9 September, 1984, p. 16.

2 M. D. Kirby, "Reforming the Law", in Alice E.-S. Tay and Eugene Kamenka (eds.), Law-Making in Australia (Melbourne: Edward Arnold, 1980), 39, at p. 55. 
Law reform, that is change, "with a view to improvement ", ${ }^{2}$ is becoming a matter of high priority in the legal systems of practically all the countries with a "unified" legal system. ${ }^{3}$ This must lead to the inference that, hardly is the desired equilibrium, in the legal system, ever attained in full measure. Thus the legal system must be kept up-todate through reform.

As Mr. Justice M. D. Kirby, the first Chairman of the Australian Law Reform Commission points out:

"The law is, necessarily, a force for stability, conservation and predictability in society. The very formal procedures through which a law must emerge, whether from the legislative, executive or judicial branches of government, tend to guarantee laws of a certain durability. Once a law is achieved, there are numerous forces which tend to obstruct change, including even change 'for the better" ". ${ }^{4}$

In hardly any society do people generally conduct themselves as if, nor let go the plain impression that, they live in the most perfect social, economic or political paradise, a paradise to which all grievance is alien. However bounteously endowed a society may be, certain most fundamental, immanent conflicts and grievances are unavoidable. This is because human comfort and satisfaction, in society, depends not only on the "horizontal" factor of economic, political or other type of endowment; it depends no less on the "vertical" factor represented by historical motion, and the compelling, attendant localised and universal changes in State relations, political atmosphere, economic and social realities, outlooks on life, etc.

Even as such momentous changes occur, extant legal systems will temporarily stand in the way of change, as it is in their "[very] nature to endure and not in their nature to change". ${ }^{5}$

Given, as already noted, that the existing law - at least where a single legal system is dominant - represents the sole yardstick of validity, and coincides with the unmistakable State monopoly in the public domain, the very first victim of dissatisfaction and social rebellion is the law in force. ${ }^{6}$ The law, and the legal system as a whole, lags behind the popular conscience and the common conception of "right"; and therefore the law is inevitably seen, as time wears on, as the foremost instrument of oppression, employed by the State against the people. ${ }^{7}$

3 L. M. Friedman, "Law Reform in Historical Perspective" (1968-69) 13 St. Louis Univ. L.J. 351; J. Beetz, "Reflections on Continuity and Change in Law Reform" (1972) 22 Univ. of Toronto L.J. 129; J. H. Farrar, Law Reform and the Law Commission (London: Sweet \& Maxwell, 1974); "Law Reform Now - A Comparative View“ (1976) 25 I.C.L.Q. 214; M. Kirby, Reform the Law (Melbourne: O.U.P., 1983).

4 M. D. Kirby, "Reforming the Law", loc. cit., p. 56.

5 George Ripert, cited in J. Beetz, loc. cit., at p. 132.

6 One of the authors was witness, in September 1984, to a good many Australian citizens standing on what they called their "social rights", in opposition to a national budget which, while its constitutional and legal validity was unchallengeable, was seen to be harsh and repugnant to the best interests of the individual.

7 It is a hypothesis worth investigating (though it is not done here), whether it is not the dialectic just remarked, that many Marxist polemicists have distorted, in their standard dogma which maintains that "law represents an institutionalised tool of those in power which functions to provide them with superior moral as well as coercive power in the conflict" - W. J. Chambliss and R. B. Seidman, Law, Order and Power (1971), p. 504, quoted in Adam Podgirecki, Law and Society (London: Routledge \& Kegan Paul, 1974), p. 276. 
But, that the state of the law should be such as to allow such an image to gain currency, is repugnant and even pernicious to the very foundation of the law itself - the foundation which holds it out as the most sanctified yardstick and instrument of public control. The resulting contradiction would also undermine the stability of the State and of all fundamental institutions in operation - a situation which would be but a few removes from the path of constructive development, and indeed of civilisation itself.

One is back, then, to law reform, ". . keeping the legal system abreast of (or helping it to catch up to) changing social circumstances and changing values . . ${ }^{8}{ }^{8}$ Achieving that end is a most elusive task. The most difficult balances must be attained. As Justice Kirby remarks:

". . the process implies the conservation of what is good in the existing order and the moulding of that which is proposed as a reform' so that it will fit comfortably into the present state of things." $" 9$

Whilst the inherently static character of the law is not to be obliterated (the law being "the 'gatekeeper of the status quo in society"),${ }^{10}$ a certain measure of adaption must be effected, so as to incorporate the effects of change in society.

But the reformers must be aware that, to some members of the society, there is something futile about the whole idea of law reform. To such members, the law reformers are seen as being more in the service of the State authorities, than in stewardship in the course of the popular conscience. Not only, the argument would go, does the law, after reform, retain the substance of the old rules, rules geared to the stability of existing institutions; but the entire scheme of reform must bear an inseparable dialectic relation to the existing structure of public authority. Iredell Jenkins comments:

"If reforms are to be accomplished, and not merely planned, they must be backed by that magic ingredient, authority. There must be some single source . . that can make decisions and issue directives that will be respected and acknowledged by all." "11

The existence of a regular and legitimate authority (which will be the existing State, as regulated under existing laws) is essential to the setting-up of the machinery of law reform, to the investing of such machinery with appropriate formal authority, and most important, to the implementation of such law-reform measures as may be recommended and duly adopted.

Reform, therefore, is reform within stability. There is no place for a "revolution", as such would have to take place outside the ambit of existing norms, ${ }^{12}$ in an unguided and, indeed, chaotic manner - a situation which would probably destroy the national heritage, as well as the constructive arrangements and orientations existing in society.

8 M. D. Kirby, "Reforming the Law", Loc. cit., p. 57.

9 Ibid.

10 Ibid.

11 Iredell Jenkins, Social Order and the Limits of Law (Princeton, N.J.: P.U.P., 1980), p. 153.

12 Cf. H. Kelsen, The General Theory of Law and State (1946), pp. 118-119. 


\section{B. Africa and Law Reform}

We propose to move now from general philosophical considerations, to illustrations of specific constraints, affecting the process of law reform. The illustrations come from the African experience, an experience that has taken place amidst some of the most challenging (and still unaccomplished) experiments in the building of basic institutions. In the infancy of the economic, social and political infrastructure, and of such attendant facilities as the democratic (legislatures, elected councils etc.), the adjudicatory (courts, tribunals etc.) and the bureaucratic (public administration, related agencies, etc.), the wielders of public authority do not merely respond to such problematic questions as those affecting law reform. They must exercise initial choices: in particular the choice between building upon, and fortif ying inherited ${ }^{13}$ institutions, and undoing and replacing such institutions with autochthonous, differently-conceived arrangements. At this initial stage, whatever choice is taken ought to be based on rational thinking. The climate for demure reflection is, however, not always present. Control of State direction of ten changes hands whimsically and irrationally, through coups d'état, rather than by way of organised, democratic vote. Thus, in addition to the dynamic context of change found everywhere, a context which tends to bring the law "out-of-fit" ${ }^{14}$ in Africa the general picture of law reform is extremely complex. In some cases initial choices have not been rationally taken by the public authorities. In others the very utility of legal change, per $s e$, is brought into question by more profound matters of economic, social and political character. ${ }^{15}$ In yet others (and this appears to be of general application), so fundamental are the conflicts engendered by the differing concept and spirit of local and imported law, ${ }^{16}$ that total confusion prevails, as to the proper direction to be taken in effecting law reform.

Difficult preliminary issues must be faced, in considering law reform in the African experience. But once such issues are accorded due treatment, one must now come to terms with the machinery and technicalities of law reform. The entire sphere of inquiry becomes so expansive, indeed, that meaningful investigation may well be only that founded upon some rough division of labour, on the basis of disciplines: between the

13 "Inheritance", in particular from Western public institutions, is, in reality, the core substance of which Af rican public institutions, by and large, are made. It all starts with the Western type model State created by the colonial powers. "Once the States were created, there was no going back. These would always have to be organised on the basis of the institutions of public law and their attendant norms ..." - J. B. Ojwang, "Legislative Control of Executive Power in English and French-speaking Africa: A Comparative Perspective", [1981] Public Law 511.

14 A. Allott, The Limits of Law (London: Butterworths, 1980), passim.

15 E.g., even though the law is reformed, affecting the landlord-tenant relations, the "justice" of the reform is hardly evident when most (or substantial number of) urban dwellers can afford only "informal", slum dwellings operated outside the purview of State law. Or, otherwise-progressive reforms have been effected in the area of employment law; but the bulk of the adult population is out of gainful employment.

16 See $n .13$ supra. See also the papers presented at the Canberra Law Workshop VII on Legal Pluralism and Comparative Law, 6-9 September, 1984. 
conventional social scientist (economist, sociologist or political scientist) and the lawyer (who, while he claims to be a social scientist, is somewhat marked as an outsider by the exceptional attention he accords the strict norm).

As we adopt a modest view of the lawyer's role, and specifically address ourselves to such "normative phenomena" as: established public organs, regulatory principles, laws and rules, we will endeavour to see these in proper context, and in particular give due attention to some of the broader considerations, to which may be ascribed the similarities or dissimilarities apparent in the Tanzanian and Kenyan law reform schemes. In treating these matters, our main focus will be on the structure and functioning of the law reform arrangements. A comparative analysis ${ }^{17}$ of these aspects, in the light of the philosophical considerations earlier considered, it is hoped, would further illuminate the basic law reform problem in Africa, thus enhancing the present level of understanding, apart from helping also to inform the conduct of the current experiments.

\section{Structure and Composition of the Law Reform Body}

It is an interesting coincidence that both Kenya and Tanzania did not see fit to establish a law reform machinery before the expiry of nineteen years from their respective dates of independence; ${ }^{18}$ and this was much more belated than had been the case in some other African countries. ${ }^{19}$ By no means does this suggest that no law reform at all had taken place in the two East African countries. It does, however, and correctly, suggest that law reform had not until so recently, been seen as an urgent and abiding concern, meriting prearranged devices for its systematic execution. In both countries the approach to law reform had been essentially random, being left to ad hoc machinery, ${ }^{20}$ dependent upon those occasions of overt emergence of specific legal perplexities. Now due, apparently, to unavoidable difficulties in the evolution of an effective body of general law (the main reasons, as already indicated, being, firstly, the existing plurality of laws; secondly, the

17 Legal scholars have expressed their belief that the comparative method, by its design of eliciting an "objective profile from a juxtaposition of different legal systems or arrangements, is one of the most effective vehicles of better legal understanding, which ought, ideally, to form an integral part of the stock-in-trade of the law reformer - see: P. Lepaulle, "The Function of Comparative Law"(1921-22) 35 Harvard Law Review 538-558; Francois Rigaux, "Le Droit comparé comme science appliquée", (1978) 55 Revue de Droit international et de Droit comparé 65-77; H. E. Yntema, "Comparative Legal Research: Some Remarks on 'Looking out of the Cave'", in (1956) 54 Michigan Law Review, 899, at p. 903.

18 Tanganyika and Zanzibar became independent from British rule, respectively, on 9 December, 1961 and 10 December, 1963. The two merged to form the United Republic of Tanzania on 27 April, 1964. Kenya gained independence from Britain on 12 December, 1963.

19 In Ghana for instance, a Law Reform Commission was set up by the Law Reform Commission Decree, N.L.C.D. 288 of 1968: see G. Woodman, Book Review in (1975) 12 University of Ghana Law Journal, 60-62.

20 E.g., in Kenya in the 1960's, Commissions of Inquiry were appointed under the Commissions of Inquiry Act (cap. 102), to inquire, respectively, into the Law of Marriage and Divorce (1967) and the Law of Succession (1967). The recommendations on the Law of Succession have since been enacted into the Law of Succession Act (cap. 160): See J. B. Ojwang and D. R. Salter, "The Law Reform Commission Act of Kenya: An Early Appraisal", (1984) 3 Civil Justice Quarterly 110. 
progress of social change), both countries have joined the growing number of Commonwealth countries with organised law reform programmes.

The Law Reform Commission of Tanzania Act ${ }^{21}$ of 1980 provides for the establishment of a Law Reform Commission, and sets out in detail the rules relating to structure and composition. ${ }^{22}$ The nucleus of the Commission is provided for in Section 5 (1) of the Act. It comprises a Chairman,,$^{2.3}$ and between four to six other Commissioners, all appointed by the President from persons of any of the qualifications specified in Section 5 (2) of the Act. An appointee is required: to hold, to have held, or to be qualified for appointment to a "high judicial office $" ; 24$ or to be an advocate in the United Republic of not less than five years' standing: ${ }^{25}$ or to be a law graduate of a University recognised by the Tanzanian Government, and who has been in legal practice for at least five years; ${ }^{26}$ or to be a teacher of law in a University or other institution of equivalent status, with at least five years' experience; ${ }^{27}$ or to be:

"a person who, in the opinion of the President, is by reason of his special qualifica-

tions, training or experience in the social economic or political affairs of Tanzania, able to contribute to the proper and effective discharge of the functions of the Commission or is otherwise suitable for appointment to the Commission. "28

The last provision, which is striking by its originality and by the manner in which it departs from the definitive but sparing character of modern legislation, recapitulates the functional link that attaches law to the internal dynamics of existing institutions. The President, as the national leader, is empowered to appoint to the law reform team a person he considers to fully appreciate the reality of Tanzanian life. Such a Commissioner's special contribution, one assumes, would be to influence the course of law reform, in a direction that does not cause a dislocation between the State's legal instrumentalities and the economic, social and political situation as it stands. It may be noted, too, that the same provision creates the opportunity to include "laymen" in the Commission, as a device to discourage "excessive bureaucracy". ${ }^{29}$

Such a perspective is hardly evident in Kenya's Law Reform Commission Act. ${ }^{30}$ This

21 No. 11 of 1980.

22 Ibid., ss. 3-6; 17-21.

23 The Chairman may, but need not, be appointed from a "high judicial of fice" - a n expression defined in Section 2 of the Act thus: "the of fice of Judge of the Court of Appeal of the United Republic or of a Judge of the High Court of the United Republic or the High Court of Zanzibar".

24 S. 5 (2) (a); and see $n .23$ supra.

25 S. 5 (2) (b).

26 S. 5 (2) (c).

27 S. 5 (2) (d).

28 S. 5 (2) (e).

29 This end is provided for in a directive principle incorporated in Section 13 (2) (c) of the Act. The provision is adverted to again, further on.

30 Act No. 2 of 1982. 
most laconic statute, substantially based on the English Law Commissions Act of 1965, provides for a Law Commission comprising a Chairman and four other Commissioners. ${ }^{31}$ That number may, however, be increased by the appointment, on the recommendation of the Chairman, of additional Commissioners "f or the purposes of a specific aspect of law reform being undertaken by the Commission ". ${ }^{32}$ Like in Tanzania, the power of appointment is vested in the President, who may make appointments for maximum terms of three years, and upon such conditions as he may deem appropriate. ${ }^{33}$ The class from which such appointments may be made is specified in Section 2 (2) of the Act:

"A person appointed to be a Commissioner shall be a person appearing to the President to be suitably qualified by holding or having held the office of judge of the High Court or Court of Appeal in accordance with the provisions of . . the constitution or by experience as an advocate or as a teacher of law in a University." This provision appears to be much more restrictive than its Tanzanian counterpart. It seems to contemplate, for membership of the Commission, only persons learned and experienced in the law, either by way of serving in high judicial office, or professional practice, or academic involvement. Indeed, in the last respect, involvement with the law has to be at University level, and not, as in the Tanzanian case, involvement at "University or other institution of equivalent status". This excludes, perhaps without justification, possible candidates for appointment who teach and promote knowledge of law at various important national centres of learning. ${ }^{34}$ (But, on the other hand, this provision of the Kenyan statute may be said to be, at least in theory, less stringent than the aspect of the Tanzanian one which stipulates the length of experience a person must have in his profession or employment, before he qualifies to be appointed a Commissioner.)

A notable contrast between the two enactments is with regard to the tenure of the Commissioners. The Tanzanian statute provides for a full-time Chairman, whose tenure is five years, and he is eligible for reappointment at the expiration of the first term. ${ }^{35}$ The other Commissioners may be full-time or part-time, and their tenure runs for three years, subject to the proviso that they, too, are eligible for reappointment. ${ }^{36}$ Any fulltime member of the Tanzanian Commission ceases to exercise the duties of his former office and devotes himself exclusively to law-reform work. The discretion allowed the President to determine whether a Commissioner (other than the Chairman) is to assume

31 Ibid., s. 2 (1).

32 Ibid., s. 2 (5).

33 S. 2 (3).

34 In this category one thinks of the Kenya School of Law, a post-University training centre that gives final preparation to law graduates before they are admitted to the legal profession; the Kenya Institute of Administration, a large Government institute offering, mainly on short term programmes, valuable training to officers from the administration and the judiciary; the Co-operative College, which teaches law as one of its main courses; the various advanced polytechnics in the country, which also offer instructions in law.

35 S. $6(1)$.

36 S. 6 (2). 
his duties on a full or part-time basis, would appear to be a deliberate device of flexibility, necessitated by considerations of changing requirements.

Under the Kenyan statute, other than the Chairman of the Commission who operates on a full-time basis, the membership is essentially part-time. ${ }^{37}$ Section 2 (4) of the Act, with reference to Commissioners holding judicial office, states:

"A person holding ... judicial office... may be appointed as a commissioner without relinquishing that office, but unless otherwise provided by the terms of his appointment, shall be required to perform his duties as the holder of that office while he remains commissioner ". ${ }^{38}$

The Kenyan statute appears no less skimpy, with regard to the terms of service for members of the Law Reform Commission. It gives no special terms of service, unlike the Tanzanian one which, in its Section 21 (1), states that the Commissioners shall be paid qua Commissioners, from the Consolidated Fund. Besides, Section 5 (5) to (7) of the Tanzanian statute clearly states that appointment as Commissioner of a holder of "high judicial office" does not operate to the prejudice of the appointee, with reference to his prior terms and conditions of service.

A. J. G. M. Sanders, writing on law reform in Africa, ${ }^{39}$ says:

"The prudent law reformer will . . . first of all, restate the existing law in scientific but understandable fashion, will then ascertain and formulate the aspirations and realities of his society, and will, finally, draft new laws when necessary".

Such is a time-consuming and onerous undertaking. The Commissioners, few and not fully available as they are, on the whole in each case, will be unable, by themselves, to perform the task effectively. Hence the need for supporting research personnel.

Under both statutes the importance of research support, for the Commissioners, is recognised. A common element in the design of such a research facility is that it originates from the regular civil service. Section 18 (1) of the Law Reform Commission of Tanzania Act provides:

"The President shall appoint, on such terms as he may determine, a public officer to be the Secretary of the Commission".

The Secretary is the Executive Officer of the Commission. ${ }^{40}$ As regards the Commission's research team, Section 19 (1) of the Act provides that the Principal Secretary ${ }^{41}$ shall, "on a recommendation by the Attorney-General, second or transfer persons holding office in the service of the United Republic to, offices under the Commission".

37 S. 2 (3) provides that a Commissioner is eligible for reappointment at the expiration of his current term.

38 From this provision it seems that, other than the Chairman (currently Mr. Justice Miller of the Court of Appeal), an additional Judge-Commissioner could serve the Commission on a full-time basis, but only if the instrument of appointment so provided. Mrs. Justice Owuor, who is a member of the Commission, serves on a part-time basis. All the other members, who are mainly practising advocates, also serve on a part-time basis: see Ojwang and Salter, loc. cit.

39 A.J.G.M. Sanders, "Comparative Law and Law Reform in Africa", in P.N. Takirambudde (ed.), The Individual under African Law (Kwaluseni: University of Swaziland, 1982), p. 148.

40 S. $18(3)$.

41 I.e., the most senoir civil servant who heads each Government department. 
Section 19 (2) empowers the Commission, "subject to any directions [given] . . by the Minister, and with the consent of the Principal Secretary", to engage on temporary terms "such persons who are experts in fields of learning relevant to any reference ..." All persons so engaged are to devote themselves exclusively to the service of the Commission during the period of their engagement..$^{+2}$ It is stipulated that any civil servant thus seconded or transferred to serve the Commission shall enjoy terms of service "not . . . less favourable than those of his previous employment ..., and his service with the Commission shall be deemed to be continuous with his previous employment in the public service for the purpose of determining the entitlement to and quantum of pension, gratuity or other superannuation benefit". ${ }^{43}$

There are no similar provisons in Kenya's Law Reform Commission Act, and it must be assumed that the make-up of the research team here is a purely pragmatic, bureaucratic arrangement which accords officers on secondment to the Commission no special position or terms of service, different from those under which they were originally employed. Section 5 of the Act states: "The Attorney-General shall make available to the Law Reform Commission the services of such public officers as are necessary for the proper and efficient exercise of the functions of the commission". In addition to this bureaucratic facility, Section 3 (1) (b) of the Act empowers the Commission to refer specific law-reform questions to nominated, outside agencies. ${ }^{44}$

The foregoing consideration of the structure and composition of the two Law Reform Commissions reveals, on one level, certain common characteristics; on another it shows one notable contrast. A modest complement of personnel, obviously a reflection of the delicate economic situation prevailing in most of Africa, is a common characteristic. Of common application, too, is the fundamental role of the President in making appointments to the Commission, thus inaugurating it in the first place and getting it started in performance of its remit. While it is true that in both countries, typified by monocephalous political leadership, crucial inauguratory functions (in particular those of constitutive character, such as appointing of judges, diplomats, etc.) are invariably conferred upon the President, it is arguable that the conferment of such a special responsibility, in the case of both Law Commissions, has a dialectic significance: as already argued, law reform, for its effectiveness, presupposes a valid, established authority. The Head of State,

42 S. 38 (6).

43 S. 19 (5).

44 If there is any opportunity for the "layman" to play a role in the law reform process, it may be that this is the provision which might facilitate such contribution, as it is possible to refer a law-reform matter to, say, women's organisations, clubs, charitable bodies, etc. 
who is the garant de l'autorite de la loi, must be the kingpin in the total set-up that initiates, implements and concludes the law reform scheme. ${ }^{45}$

It is arguable, further, that the foregoing point is little affected by the specific political direction followed by a particular State, considering in particular that Tanzania and Kenya, in this matter, share common ground even though the former, since 1967, has adhered to a socialist programme, ${ }^{46}$ even as Kenya has maintained, and even strengthened the essentially capitalist institutions inherited at independence. ${ }^{47}$

Although the common use, in both countries, of bureaucratic facilities, as supports to the law reform programme, may be attributed to considerations of economy, or to prevailing inadequacy of the legal infrastructure, we take the position that, to some extent, this characteristic bears a relation to the logic already convassed, that the State machinery is a critical, ultimate factor in all law reform.

Once such broad similarities are noted, it is to be remarked also that the Tanzanian Law Commission, and its research staff, are more formally defined and minutely provided for than its Kenyan counterpart. This kind of contrast, which will become still more evident, is to be borne in mind as we consider the functions of the two Commissions, and in particular as we reflect on the relative scope for "independent" management of the law reform programme.

\section{Function of the Law Reform Body}

The broad function of both Commissions is stated in almost identical terms. Section 4 (1) of the Tanzanian statute states:

"The functions of the Commission shall be to take and keep under review all the law of the United Republic with a view to its systematic development and reform".

Section 3 (1) of the Kenyan Act provides:

"It shall be the function of the Law Reform Commission to keep under review all the law of Kenya to ensure its systematic development and reform ..."

The scope of such a function may be gleaned from subsequent provisions. Section 4 (2) of the Tanzanian Act provides that "[i]n particular, but without prejudice to the generality of subsection (1)", the Commission may undertake a review of any law or branch of law, ultimately proposing measures for: "bringing that law ... into accord with current circumstances in Tanzania";48 "eliminating anomalies or other defects in the law,

To what extent this allows of independence in the detailed discharge of law-reform work is to be considered later.

46 R. Martin, Personal Freedom and the Law in Tanzania (Nairobi: O.U.P., 1974); D. Williams, "Law and Socialist Rural Development" (1973) 6 Eastern Africa Law Review 193-213.

47 Y.P. Ghai and J.P.W.B. McAuslan, Public Law and Political Change in Kenya (Nairobi: O.U.P., 1970).

48 S. 4 (2) (a) (i). 
repealing obsolete... laws and reducing the number of separate enactments"; $;$ "the proper codification and simplification of that law or branch of law ". ${ }^{50}$

Section 3 (1) of the Kenyan statute incorporates, more concisely, the same object, specifiying that the remit to "keep under review all the law" includes "in particular the integration, unification and codification of the law, the elimination of anomalies, the repeal of obsolete... enactments and generally its simplication and modernisation". The substantial likeness ${ }^{51}$ should not, however, obscure a possible area of dissimilarity. From the provisions just cited, one might well argue that the Kenyan statute appears more motivated by the objects of definitiveness and modernity, somewhat at the expense of what the Tanzanian Act refers to as "local circumstances".

"Local circumstances" is a n imprecise expression which might suggest to law reformers an engagement in complex, non-legal inquiries, especially in social, economic and political spheres. It is true, however, that matters of such complexion must be taken into account in any scheme of law reform. As we have maintained elsewhere, any genuine law reform effort would have to take into account, inter alia, the following questions:

"(i) what are the needs ... of society;

(ii) does the existing law ... adequately cater for those needs . ..;

(iii) if not, what changes can be recommended to alter the law ... in order to rectify the incongruence $" .52$

Our proposition there assumes a dynamic context in which questions such as those involving customary laws, are in the throes of change, owing to the constraints of a modern State regulated by an increasingly centralised legal system.

Just as it is not clear that the Tanzanian statute envisages this dynamic element in society, ${ }^{53}$ so is it not evident that the Kenyan statute would limit the reform initiative to the dictates of social change; nor obvious that the latter statute does not contemplate "modernisation" as a device that will facilitate a measure of value-importation. ${ }^{54}$ It is not only with regard to substantive law that the Tanzanian statute gives a role to the Commission; the Commission is also to ensure effective application of the law. Section 4 (2) (b) provides that the Commission may "consider and advise on [proposals] for the adoption of new or more effective methods for the administration of the law and the dispensation of justice". Although there is no similar provision in the Kenyan statute, it is arguable that the broad terms of Section 3 (1) (already referred to) must imply a

49 S. 4 (2) (a) (ii).

50 S. 4 (2) (a) (iii).

51 This leaves no doubt that both Parliaments were, in their deliberation, influenced by the draftsmanship of the English legislation of 1965, setting up the Law Commission for England and Wales.

52 J. B. Ojwang and D. R. Salter, "The Law Reform Commission Act of Kenya: An Early Appraisal", loc. cit., p. 114.

53 This is not evident, even though (as already noted) the President may appoint a Commisioner with expertise in social, economic and political matters.

54 In its Report of 1968, Kenya's Commission on the Law of Succession (see no. 20, supra), at Para. 11 directed itself in instructive terms quoted in the text in the passage accompanying footnote 66. 
responsibility in respect of both the substance of the law and the effectiveness of application.

It is clear that the Law Reform Commission is the special agency, in either case, entrusted with the all-important function of keeping the legal system adjusted to the motion in society, and as a basis of continued stability. What is in neither case plain is whether the Commission has any independent constitutional or legal responsibility for the law reform process.

One limitation on the operational autonomy of the Commissions is evident from the start. However independently they might arrive at a law reform proposal, the same is devoid of effect until it is introduced before the Legislature in the form of a Bill, debated and approved. And even when such proposals should ultimately become law, they will remain subject to the enforcement initiative of the Executive, as was suggested earlier on.

Further provisions of both Acts leave little doubt that the Commissions have no autonomous or exclusive legal domain. Section 2 (1) of the Kenyan statute states that the Commission is established "[f]or the purpose of promoting the reform of the law".$^{55}$ This is not the same thing as effecting reform.

How does the Commission promote reform? From subsequent provisions, it is clear that the Kenyan Commission has a basic dual mandate. Firstly, it serves as an advisory body to the Attorney-General, in matters of law reform generally. Secondly, it serves as a consultative body, charged with the duty of providing "advice and information to ministries and departments of the Government, with regard to the reform or amendment of a branch of the law appropriate to that ministry or department $" .{ }^{56}$

Whichever is the origin of a reference to the Commission, the Kenyan Act places upon the commission the mantle of responsibility to "prepare and submit to the AttorneyGeneral programmes for the examination of different branches of the law with a view to reform "..$^{57}$ No restriction is placed upon the Commission in its choice of areas of law which it deems ripe for reform. Similarly there is no statutory definition of the forms which programmes for reform, submitted to the Attorney-General, should take. The Commission is free to determine its own scheme of priorities, in matters of law reform. The main limitation to this relative autonomy is that the fate of programmes submitted by the Commission depends on the Attorney-General. Progress towards a reformed law can only take place if the chief legal officer of the Government, in his discretion, approves the programmes submitted to him and authorises the Commission, under Section 3 (i) (c) of the Act, "to [proceed to] undertake ... the examination of particular branches of the law ..., by means of draft Bills ..." Only after this second stage is complete will the Attorney-General be under a duty to "lay before the National

55 Emphasis added.

56 S. 3 (1) (e). (Besides the foregoing functions, it appears from s. 3 (1) (a) that the Commission is conceived as a general reference body, to which any question of law reform may be referred, by any institution, or indeed any person)

57 S. 3 (1) (b). 
Assembly [the] programme prepared by ... Commission . . . and any proposal for reform formulated by the ... Commission pursuant to the programme ". ${ }^{58}$ In this way the Attorney-General is able to control and determine the trend and direction of the law reform process in Kenya. He will, no doubt, base his decision upon political as well as legal considerations; for such will reflect the wishes of the Executive as regards the priority areas of law reform. ${ }^{59}$

The initiative of Government is still more evident in the Tanzanian statute. Section 7 provides:

"The Minister [in charge of legal affairs] may from time to time, after consultation with the Attorney-General, give the Commission directions of a general or specific nature in relation to the performance of its functions, and the Commission shall comply with every such direction. "60

What such binding directions involve is not entirely clear; but one assumes that they would concern working procedures, determination of law reform priorities, etc. If the assumption is correct, it would follow that the Commission is intended to serve, inter alia, as a regular governmental agency for conducting preliminary investigations before Bills are introduced in Parliament. ${ }^{61}$

Section 8 (1) of the Tanzanian Act provides that "[s]ubject to any directions given by the Minister, the Attorney-General shall, from time to time, refer to the Commission matters which the Commission may ... examine ... and make recommendations with a view to reforming the law . . $1{ }^{62}$ From this phraseology, one may think that the Commission, after all, has a discretion in acting on a matter referred to it by the AttorneyGeneral. But in the light of the provision for Government to exercise control over the functioning of the Commission, ${ }^{63}$ the provision for independent discretion appears to be more theoretical than real. ${ }^{64}$

As a basis for the reform of the law of succession, Kenya's Commission of Inquiry on the

58 S. 3 (2). (See also s. 3 (1) (d)).

59 Cf. the Memorandum of Objects and Reasons accompanying the Law Reform Commission Bill, which stated: "The object of this Bill is to establish a . . neutral body which shall examine objectively proposals for reform and generate, of its own volition, proposals for law reform in areas not specifically selected by interested parties".

60 Emphasis added. (By ss. 10 and 11, the Commission is minutely directed as to how it will proceed upon its task - e.g., by holding seminars, arranging public lectures, promoting public debates, preparing a publiccirculation bulletin, using committees, obtaining contribution through ministerially-directed co-optation, etc. This is a far cry from the Kenyan position, in which the Chairman of the Commission takes basic responsibility for the preparation of the operative standing orders.)

61 The closest the Kenyan statute gets to that position is in s. 3 (1) (d), which provides that at the request of the Attorney-General, the Commission may "prepare ... comprehensive programmes of consolidation to facilitate the exercise by him of his powers under the Revision of Laws Act ..."

62 Emphasis added.

63 N. 60, supra. The position is clearer still from s. 8 (3) of the Act which gives the Attorney-General various grounds of control over the working of the Commission.

64 Cf. S. 12 of the Act, which provides: ". . the Commission shall in the performance of its functions ... act independently in its deliberations and formulation of its recommendations". 
Law of Succession (already referred to) of 1967 had to take an independent initiative in the formulation of policy guidelines. In its Report ${ }^{65}$ the following remark appears: ${ }^{66}$

"We agreed that the new law should generally be compatible with the African way of life, and should not be based on any foreign model. On the other hand, the law should recognise that the traditional African way of life is rapidly changing and should therefore cater for differing conditions ..."

To what extent do the law reform statutes provide any guidelines for the Law Reform Commissions? And, if guidelines are provided, how far do they allow the exercise of independent initiative in the consideration of material issues affecting law reform?

In the experience of countries elsewhere, it is not always obvious, nor provided for, what specific policy considerations should guide a law reform body. One-time English Law Commissioner, Professor L.C.B. Gower, once tried to articulate the kind of philosophy that had instinctively guided them in their recommendations for law reform. He said:

"... I guessed that we adopted a vague utilitarianism, asking ourselves (subconsciously rather than consciously) what would conduce to the greatest good of the greatest number. $11^{67}$

It is most difficult to articulate in specific terms the policy considerations which ought to be taken into account in effecting law reform. Kenya's Law Reform Commission Act, for instance, makes no attempt to formulate any policy guidelines, and it must be assumed that the Commissioners are to make their own value judgments, in the light of the trends in Kenyan life, and of common sense.

The Tanzanian Parliament, interestingly, undauntedly endeavoured to set specific guidelines for the conduct of law reform. The Commission is required to: "take into account the need for having in Tanzania laws which . . . facilitate the . . policy of Ujamaa and self-reliance"; 68 ensure that the Tanzanian laws "promote and expand the principles and practice of human equality and freedom "; 69 suggest legal reforms which "promote and secure the decolonisation of the law of Tanzania by the refinement of . . . the customs, traditional values and beliefs . . " $;^{70}$ "promote interest in, and ensure respect for, the rule of law by discouraging arbitrariness, of ficialism and excessive bureaucracy". ${ }^{71}$

Most of these policies are transparently nebulous, and could hardly be said to vest in the Law Reform Commissioners a definite mandate. Yet a number of these policies already form part of the Constitution of the sole political party, the Chama Cha Mapinduzi (Revolutionary Party). In the circumstances it, perhaps, ought to be assumed that the accepted content of the obligations imposed by a policy to "promote . . . the decolonisation of the law", or to "facilitate the policy of Ujamaa", etc. must be the one articu-

65 Report of the Commission on the Law of Succession (Nairobi: Government Printer, 1968).

66 Para. 11.

67 L.C.B. Gower, "Reflections on Law Reform" (1973) 23 University of Toronto Law Journal 257, 268.

68 S. 13 (1).

69 S. 13 (2) (a).

70 S. 13 (2) (b).

71 S. $13(2)(c)$. 
lated by the Party, as the supreme political organ; and the Commissioners are not to be expected to pursue any unauthorised course, in articulating the fundamental questions dictating their judgment in law reform proposals. ${ }^{72}$

The scope for independent discretion, in matters of value judgment, is an area of striking contrast between the law reform arrangements in Tanzania and Kenya. One might raise a question as to the significance of autonomy in a law reform agency, in the one-party State in which one political platform is entrenched, and practically all public agencies operate in one broad system of consensus. The conviction seen to be carried in such a view will vary, depending on the persuasion of an individual. To our minds it is plain that, since in a one-party State (such as is the case in both Tanzania and Kenya) the scope for the expression of views contrary to party policy tends to be limited, it will be a trenchant safety valve for the political system, if as many regular outlets as possible were made available for independent thought, by individuals and by such important entities as Law Reform Commissions. Given such outlets, the Commission's proposals (which in any case could only become law through the democratic act of the Legislature) are more likely to approximate to reality, in their reflection of social change, than if they were merely to echo the well-known commitments of the Executive.

\section{Concluding Remarks}

Starting from a consideration of some of the philosophical issues affecting law reform, this article has proceeded to focus attention on the frameworks of reform recently enacted in Tanzania and Kenya. The general constraints on law reform are shown to be in operation in both countries, where social change is seen as such a critical aspect of the process of national development; yet that change must take place on the basis of overall stability, sustained by the legal process. It is most problematic discovering a happy medium between the strains of social change, and the inherently dilatory and even static responses of the law.

Neither country can claim to have located that intermedium. But, while the Kenyan law reform framework would permit further endeavour in that search (by allowing the Law Reform Commission a substantial measure of discretion in the manner of determining priorities and of examining particular laws), the Tanzanian legislation commits the Commission to certain broad goals, which are regarded by the State as being in the best interest of the Tanzanian people.

Such a remarkable distinction notwithstanding, this study has shown that the two schemes of law reform share many common features, in particular with regard to the place of Government machinery in the conduct of law reform.

The study has been undertaken with a full awareness that the Law Reform Commissions of Tanzania and Kenya are entirely new, and thus could not at this stage allow of any

72 Cf. fn. 64, supra and accompanying text. 
extensive practical account. We were, however, convinced that the starting point in the study of law reform, with reference to the African experience, must be a clear framework of informing ideas. The philosophical foundation must be clear, just as the legal mechanisms must be understood, as a basis for practical assessment which is left for the future. We have attempted to lay that basis through the comparative method: an attempt "to bring into an approximately sensible juxtaposition at least two systems of law... and ... to see in each something of its own native quality ...". ${ }^{73}$ We have sought to clarify the law reform arrangements in the two countries, at every turn comparing and contrasting, in the light of relevant matters of principle or policy.

As C.J. Hamson has noted: "It is from an awareness of peculiarities and differences that we may arrive at an understanding of the nature or essence of the thing with which we are concerned, of what Aristotle called the specific and specifying characteristic ". ${ }^{74}$ We hope the reader's understanding will be enhanced as he can see the Tanzanian law reform experiment in the mirror of the Kenyan one, and vice versa.

73 C. J. Hamson, The Law: Its Study and Comparison (Cambridge C.U.P., 1955), pp. 28-29.

74 C. J. Hamson,"The Comparative Study of Law", in C. J. Hamson and T.F.T. Plucknett, The English Trial and Comparative Law (Cambridge: Heffers, 1952), p. 8. 


\title{
ABSTRACTS
}

\section{Law Reform in Africa: A Comparative Study of the Tanzanian and Kenyan Experiments}

\author{
By D. R. Salter and J. B. Ojwang
}

This article begins with an outline of the general philosophical issues affecting law reform and seeks to identify those issues which have a particular relevance to African countries. Further it reveals that the general constraints on law reform are present in Tanzania and Kenya and in particular, the need to balance the desire for social change as a goal of national development with the necessity to ensure that any change is so ordered as to maintain a stability within society which is sustained by the legal process.

In this context, the article examines the provisions of two recent statutes, The Law Reform Commission of Tanzania Act (1980) and The Law Reform Commission Act (1982) of Kenya, which introduced in the respective countries law reform bodies charged with the duty of promoting law reform. Particular attention is given to a comparative analysis of the structure, composition and functions of these bodies.

The overall, and, perhaps, surprising conclusion reached (bearing in mind the disparity between the the countries declared political standpoints) is that the two schemes of law reform enjoy many common characteristics not least of which is the prominance of the Government machine in the conduct of law reform.

\section{"From Native Courts to People's Local Courts: The Politics of Judicial Administration in Sudan«}

\section{By Musa Adam Abdul-Jalil}

The paper traces the development of native courts in Sudan since the turn of this century to the present time and attempts to explain the various reform measures (introduced by different governments) in terms of the political interests of those in power. Introduced by the British as a part of the policy of "Indirect Rule", native courts have remained until now the agents of the central governments for controlling rural populations.

The last decade has witnessed three reform attempts, all of which have failed to produce satisfactory results as far as the rural people are concerned. A 1973 act abolished the native courts together with the native administration system and instituted people's courts and people's councils instead. This was an indication of the socialist tendencies of the government at that time. A second reform in 1976 made minor adjustments to deal with 